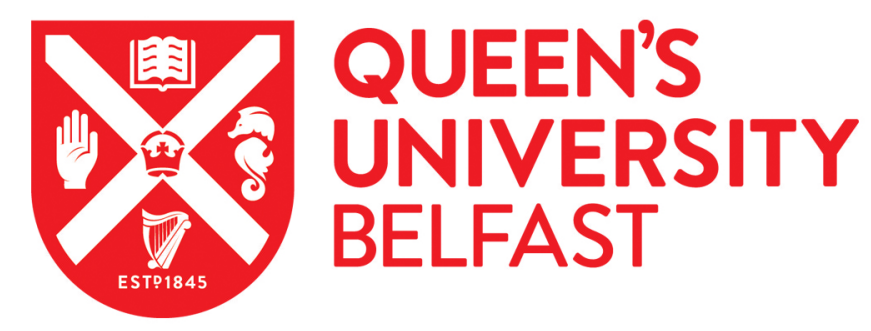

\title{
Boiling Licorice Produces Self-assembled Protein Nanoparticles: A Novel Source of Bioactive Nanomaterials
}

Zhou, J., Zhang, J., Gao, G., Wang, H., He, X., Chen, T., Ke, L., Rao, P., \& Wang, Q. (2019). Boiling Licorice Produces Self-assembled Protein Nanoparticles: A Novel Source of Bioactive Nanomaterials. Journal of Agricultural and Food Chemistry. https://doi.org/10.1021/acs.jafc.9b03208

Published in:

Journal of Agricultural and Food Chemistry

Document Version:

Peer reviewed version

Queen's University Belfast - Research Portal:

Link to publication record in Queen's University Belfast Research Portal

Publisher rights

(c) 2019 American Chemical Society. This work is made available online in accordance with the publisher's policies. Please refer to any applicable terms of use of the publisher.

\section{General rights}

Copyright for the publications made accessible via the Queen's University Belfast Research Portal is retained by the author(s) and / or other copyright owners and it is a condition of accessing these publications that users recognise and abide by the legal requirements associated with these rights.

Take down policy

The Research Portal is Queen's institutional repository that provides access to Queen's research output. Every effort has been made to ensure that content in the Research Portal does not infringe any person's rights, or applicable UK laws. If you discover content in the Research Portal that you believe breaches copyright or violates any law, please contact openaccess@qub.ac.uk. 


\section{Boiling Licorice Produces Self-assembled Protein Nanoparticles: A Novel Source of Bioactive Nanomaterials}

Jianwu Zhou, ${ }^{1}$ Jian Zhang,,${ }^{1}$ Guanzhen Gao, ${ }^{1}$ Huiqin Wang, ${ }^{1}$ Xiaoyan He, ${ }^{2}$ Tianbao Chen, ${ }^{3}$ Lijing Ke*1, Pingfan Rao, ${ }^{1}$ Qiang Wang ${ }^{4}$

\footnotetext{
${ }^{1}$ Food Nutrition Sciences Centre, School of Food Science and Biotechnology, Zhejiang Gongshang University, Hangzhou 310012, China

${ }^{2}$ Institute of Biotechnology, Fuzhou University, Fuzhou 350000, China

${ }^{3}$ School of Pharmacy, Queen's Univeristy Belfast, Belfast BT9 7BL, United Kingdom

${ }^{4}$ Institute of Food Science and Technology, Chinese Academy of Agricultural Science, Beijing 100193, China
}

*Corresponding author: Lijing Ke, Ph.D., Associate Professor

Email: lijingke@zjgsu.edu.cn; Tel: +86 57188086706 


\begin{abstract}
As a popular ingredient for western and traditional Chinese medicine, the root and rhizome of Chinese licorice (Glycyrrhiza uralensis Fisch.) is often administered in the form of decoction. The protein nanoparticles (NPs) self-assembled during the process of decoction. A major constitutive protein (GLP) was purified and determined to have a molecular weight of $28 \mathrm{kDa}$ with N-terminal sequence of NPDGL IACYC GQYCW. Over $80 \%$ of the purified GLP selfassembled into spherical NPs with diameters of $74.1 \pm 0.7 \mathrm{~nm}$ and $\zeta$-potential of $-24.3 \pm 1.7 \mathrm{mV}$ when it was boiled in Tris- $\mathrm{HCl}$ buffer $(\mathrm{pH}=7.9,20 \mathrm{mM})$ at $100^{\circ} \mathrm{C}$ for $60 \mathrm{~min}$. Each nanoparticle was estimated by SEC-MALLS approach to be composed of approximately 23 protein molecules. The NPs and GLP showed low cellular toxicity upon four types of cells including MDCK, L-02, HepG2 and Caco2 cells, while the NPs promoted proliferation of normal hepatocytes by $67 \%$. The NPs solubilized the insoluble astragaloside IV by encapsulation. Results suggest a great potential for GLP-NPs as a promising prototype of drug vehicle, a novel source of bioactive nanomaterials from herbal proteins, as well as a new mode of function with herbal components.
\end{abstract}

\title{
KEYWORDS
}

Glycyrrhiza uralensis Fisch.; licorice proteins; nanoparticles; nanocarriers; astragaloside IV. 


\section{INTRODUCTION}

Licorice, the root and rhizome of Glycyrrhiza uralensis Fisch. (Radix Glycyrrhizae, GanCao, Chinese licorice), is a popular food ingredient and a common ingredient for both Western and Eastern medicines. In traditional Chinese medicine (TCM), licorice is one of the oldest and most frequently prescribed herbs. ${ }^{1}$ It appears in 26,185 of 96,592 formulae records, as indicated by the result of data mining and frequency analysis on TCM formulae. ${ }^{2}$ Besides its various proved biological activities, such as anti-inflammatory, antiulcer, anti-cancer antioxidant and anti-viral effects, ${ }^{3}$ licorice plays very important roles in harmonizing and modifying other herbs in a prescription according to TCM theory, whose mechanism still remains unknown to date.

Heat processing is a common process in the preparation of licorice containing foods or herbal medicines. The dried and sliced licorice roots are usually mixed with other herbs and boiled to prepare a TCM decoction. On the other hand, the boiling water extract of licorice is widely used as a sweetener in food industry. ${ }^{4}$ What is notable is that boiling water extraction of herbs can result in the generation of micro- or nano- scale colloidal particles. These heat-induced colloidal particles can tolerate the gastro-intestinal environment and are correlated to the pharmaceutical activities of the decoction. ${ }^{5}$ The therapeutic functions of these colloidal micro/nano-particles may be attributed to the bioactive phytochemicals that they are carrying. ${ }^{6}$ Moreover, investigations on chemical and structural properties of these herbal colloidal particles reveal that the macromolecules, i.e., proteins, are in many cases the major components of their scaffold. ${ }^{7,8}$

There is an increasing interest in recent years in fabricating micro-/nano-particles for drug or nutraceutical delivery, in hope to improve the stability and bioavailability of medicinal or nutraceutical ingredients. Protein nanoparticles are of paramount importance among nanoparticles, because they are non-toxic and biodegradable. ${ }^{9} \mathrm{~A}$ range of proteins have been 
used to fabricate nanoparticles, including zein, whey proteins, soy proteins and caseinate. ${ }^{10}$ These proteins are mostly GRAS (generally recognized as safe) food-grade ingredients. ${ }^{11}$ It is worth noting that herbal proteins remain an unexplored hidden treasure chest for scientists working in nanotechnology and nanomaterials. Many of them can assemble into nanoparticles spontaneously during the boiling water extraction, i.e. licorice protein nanoparticles can logically be considered as GRAS for they have been consumed in the form of decoction with a long history, although surprisingly unaware. It is rational to expect these protein nanoparticles would raise much less safety concern than other particles prepared from novel protein source with much shorter application history as food.

In this study, a major constitutive protein of licorice was purified and characterized. The purified licorice protein was used to prepare nanoparticles by boiling in aqueous solution. Harvested licorice protein nanoparticles were subsequently determined for their morphological profiles, granular properties, $\mathrm{pH}$ response, drug loading capability and cytotoxicity on four types of cells, e.g. MDCK, L-02, HepG2 and Caco-2 cells.

\section{MATERIAL AND METHODS}

\subsection{Preparation of licorice decoction}

The Glycyrrhiza uralensis Fisch., root and rhizome, honeyed (Radix Glycyrrhizae, Gan-Cao, licorice root), purchased from Beijing Shuangqiao Yanjing Medicinal Material Factory, Co., Ltd. and authenticated by Prof. Chengzi Yang from Fujian University of Traditional Chinese Medicine. Voucher specimens were deposited at the Museum of Traditional Chinese Medicine, Fujian University of Traditional Chinese Medicine, under the identification code: Radix Glycyrrhizae_(SQYJ-201106062NM1202). Nine grams of licorice were soaked in $200 \mathrm{~mL}$ distilled water for $20 \mathrm{~min}$ at room temperature (around $25^{\circ} \mathrm{C}$ ) with stirring, then subsequently boiled at $100^{\circ} \mathrm{C}$ for $30 \mathrm{~min}$, cooled to room temperature and filtered through two layers of 
cotton gauze. The filtrates were centrifuged at $12000 \mathrm{~g}, 25^{\circ} \mathrm{C}$ for $15 \mathrm{~min}$ to collect the supernatant, labelled as 'licorice decoction'.

\subsection{Purification and characterization of Glycated Licorice Protein (GLP)}

The sundried slices of licorice roots $(200 \mathrm{~g})$ were ground and extracted with $1000 \mathrm{~mL}$ sodium phosphates buffer $(0.02 \mathrm{M}, \mathrm{pH} 7.2+0.1 \mathrm{M} \mathrm{NaCl})$ at $4^{\circ} \mathrm{C}$ for $12 \mathrm{~h}$. The extracts were filtered with two-layer cotton gauze to remove the sediments. The filtrates were centrifuged $(12,000 \mathrm{~g}$ at $4{ }^{\circ} \mathrm{C}$ for $15 \mathrm{~min}$ ), and the suspension was collected as licorice protein extract. The $\mathrm{pH}$ of protein extract was adjusted to 10 using ammonia solution and subjected to the ethanol precipitation at $4{ }^{\circ} \mathrm{C}$. The precipitates between $40 \%$ to $50 \%$ ethanol were collected by centrifuge at $12,000 \mathrm{~g}$ at $4^{\circ} \mathrm{C}$ for $15 \mathrm{~min}$, and then re-dissolved in Tri-HCl buffer (0.02 M, pH 8.0).

Eighty millilitres of licorice extracts were loaded onto an anionic exchange chromatographic column (Macro-Prep ${ }^{\circledR} H i g h-Q$, Bio-rad, $1.0 \mathrm{~cm} \times 25 \mathrm{~cm}$ ) equilibrated with $20 \mathrm{mM}$ Tris-HCl buffer $(\mathrm{pH} 8.0)$ at flow rate $1.0 \mathrm{~mL} / \mathrm{min}$, and then eluted with a linear $\mathrm{NaCl}$ gradient $(0-1.0 \mathrm{M}$, $200 \mathrm{~min}$ ) followed by rinsing with $1.0 \mathrm{M} \mathrm{NaCl}$ in the same buffer for $20 \mathrm{~min}$. The eluates were monitored spectrophotometrically at $280 \mathrm{~nm}$ and collected around chromatographic peaks. The fraction (A2) containing the target protein was dialysed, and then applied to a hydrophobic column $($ POROS $\AA$ R1, Bio-rad, $1.0 \times 20 \mathrm{~cm})$ equilibrated with deionized water at a flow rate of $0.5 \mathrm{~mL} / \mathrm{min}$, and then eluted with a linear $\mathrm{NaCl}$ gradient $(0-1.0 \mathrm{M}, 60 \mathrm{~min})$. The eluate was monitored at $280 \mathrm{~nm}$. The collected fractions were subjected to gel electrophoretic analysis.

Protein concentration was determined by Lowry assay, ${ }^{12}$ using bovine serum albumin as standard preparations. Sodium dodecyl sulfate-polyacrylamide gel electrophoresis (SDSPAGE) was performed, using $4.0 \%$ polyacrylamide as concentrating gel and $12.5 \%$ polyacrylamide as separating gel. The molecular weight was determined according to the method of Laemmli and Favre. ${ }^{13}$ N-terminal sequence of amino acids of the target protein was 
identified by Edman degradation performed with a Protein Sequencer 476 (Applied Biosystems, Perkin-Elmer Co., USA).

\subsection{Preparation of heat-induced GLP nanoparticles (GLP-NPs)}

The GLP $(1.0 \mathrm{mg} / \mathrm{mL})$ was dialyzed in deionized water to remove salts of the eluate buffer of the previous chromatographic separation and then adjusted with $1 \mathrm{M} \mathrm{HCl}$ or $2 \mathrm{M} \mathrm{NaOH}$ to $\mathrm{pH} 1.1,1.8,2.1,2.9,3.6,4.7,5.7,6.8,7.9,8.9,9.8,10.8,11.7,12.8$ and 13.6 , then filtered with $0.45 \mu \mathrm{m}$ cellulose acetate membrane. The preparations were incubated at different temperatures, i.e. $30,40,50,60,70,80,90$ and $100^{\circ} \mathrm{C}$ for $60 \mathrm{~min}$, then cooled in ice-water bath for $30 \mathrm{~min}$, and then filtered with $0.22 \mu \mathrm{m}$ cellulose acetate membrane. The filtrates were collected for further analysis.

\subsection{Size-Exclusion Chromatography with Multi-angle Laser Light Scattering (SEC-} MALLS)

The GLP-NPs or GLP solution was applied to a pre-equilibrated (0.02 M Sodium phosphates buffer, $\mathrm{pH} 7.2)$ size-exclusion gel chromatography (TSK G6000PW) column $(7.8 \mathrm{~mm} \times 30 \mathrm{~cm})$ equipped with a HPLC system (LC2010, SHIMADZU Co., Japan).

The column was eluted with the citrate buffer at a flow rate of $0.5 \mathrm{~mL} / \mathrm{min}$. The elutes were continuously monitored with a UV detector and a multi-angle laser light scattering detector (MALLS, Dawn EOS, Wyatt Technology, CA) to obtain the absorbance at $280 \mathrm{~nm}$ and light scattering intensity at $690 \mathrm{~nm}$, respectively.

\subsection{The Assembly Efficacy of GLP-NPs}

The GLP-NPs were assembled by heating GLP solution $(1.0 \mathrm{mg} / \mathrm{mL})$ at $100^{\circ} \mathrm{C}$ for $60 \mathrm{~min}$ in Tris- $\mathrm{HCl}$ buffer $(\mathrm{pH}=7.9,20 \mathrm{mM})$. The assembly efficacy was then calculated using the Equation (1) below. For ultrafiltration, GLP-NPs dispersion (1 mL) was separated with ultrafiltration tube (molecular weight cut-off $100 \mathrm{kDa}$ ) at $25^{\circ} \mathrm{C}, 5000 \mathrm{~g}$ for $60 \mathrm{~min}$. The 
filtration tube was washed with $1 \mathrm{~mL}$ buffer twice. The GLP solution $(\mathrm{C})$ and filtrates $\left(\mathrm{C}_{1}\right)$ were collected and subjected for protein content determination by the gel filtration chromatography and Folin-Phenol assay, respectively.

$$
\mathrm{AE}=\left(\mathrm{C}-\mathrm{C}_{1}\right) / \mathrm{C} \quad \text { Equation }(1)
$$

AE: Assembly Efficacy; C: GLP content; $\mathrm{C}_{1}$ : Free GLP content in dispersion

\subsection{Molecular Mass and Particle Radius Determination of GLP-NPs}

Data obtained from MALLS were analyzed using Astra software (Version 5.3.4.20, Wyatt Technology, CA). The weight-average molecular mass $\left(\mathrm{M}_{\mathrm{w}}\right)$ and $\mathrm{z}$-average radius of gyration $\left(\mathrm{R}_{\mathrm{z}}\right)$ were calculated using the following equations:

$$
\frac{R_{\theta}}{K^{*} \mathrm{C}}=M_{w} P(\theta)-2 A_{2} C M_{w}^{2} P^{2}(\theta) \quad \text { Equation (2) }
$$

Where $R_{\theta}$ is the excess Rayleigh ratio. $P(\theta)$ is the particle scattering factor, which is approximately equal to $1-2 \mu^{2}\left\langle r^{2}\right\rangle / 3 !+\ldots$, where $\mu=(4 \pi / \lambda) \sin (\theta / 2)$. c is the concentration of the nanoparticles $(\mathrm{g} / \mathrm{mL}) . \mathrm{M}_{\mathrm{w}}$ is the weight-average molecular mass $(\mathrm{g} / \mathrm{mol}) . \mathrm{A}_{2}$ is the second virial coefficient $\left(\mathrm{mol} \mathrm{mL} / \mathrm{g}^{2}\right)$, and $\mathrm{K}^{*}$ is a constant. For vertically polarized incident light with a wavelength $\lambda_{0}$ in vacuum, $K^{*}$ is given by:

$$
K^{*}=\frac{4 \pi^{2} n_{0}^{2}}{\lambda_{0}^{4} N_{A}}\left(d_{n} / d_{c}\right)^{2}
$$

where $n_{0}$ is the refractive index of the solvent at wavelength $\lambda_{0}, \mathrm{~N}_{\mathrm{A}}$ is Avogadro's number and $\mathrm{d}_{\mathrm{n}} / \mathrm{d}_{\mathrm{c}}$ is the specific refractive index increment of the fractions, which of $0.119 \mathrm{~mL} / \mathrm{g}$ was used in this calculation.

A plot of $\left(\mathrm{K}^{*} \mathrm{c}\right) / R \theta$ vs. $\sin ^{2}(\theta / 2)$ (Debye plot) was constructed at each retention time, which is the classical elaboration of light scattering data from which the molecular weight and RMS radius distributions are estimated. $\mathrm{M}$ can be directly determined from the intercept at zero angle, 
whereas, the slope yields the mean square radius. If the concentration is sufficiently small than $A_{2} c=0$, and Eq. (1) is solved for $A_{2}=0$, than for the molecular weight and RMS radius one obtains the following equations:

$$
M=\frac{R_{0}}{K^{*} C}
$$

and for: $\left\langle r^{2}\right\rangle^{1 / 2}$

$$
\left\langle r^{2}\right\rangle^{1 / 2}=\frac{\sqrt{3 \lambda_{0}}}{4 \pi n_{0}} \sqrt{m_{0} M_{w}}
$$

\subsection{Cell culture, Cytotoxicity and Cellular Viability}

Four cell lines of different organellar origins, i.e. human colon adenocarcinoma (Caco-2) cells, human hepatoblastoma (Hep-G2) cells, Canine kidney epithelia (MDCK) cells and human normal hepatocytes (L-02), were used to evaluate the influence of licorice protein and the GLP-NPs on the cellular viabilities. The rat alveolar macrophage (NR8383) cells were used to evaluate the immune-stimulating activity of the protein and NPs. Among them, the Caco-2, Hep-G2 and MDCK cells are carcinoma cells while the L-02 and NR8383 are normal cells. The assayed sample concentrations were $256,128,64,32,16 \mu \mathrm{g} / \mathrm{mL}$ for the licorice protein and $224,112,56,28,14 \mu \mathrm{g} / \mathrm{mL}$ for the GLP-NPs.

In brief, samples were subjected to the cells pre-cultured in 96-well plates with 4 duplicates for each concentration, and cultured at $37^{\circ} \mathrm{C}, 5 \% \mathrm{CO}_{2}$ for $48 \mathrm{~h}$. The cellular viability was then assessed by cell proliferation (MTT assay), ${ }^{14}$ and presented as the percentage of viable cells (Means $\pm \mathrm{SD}, \mathrm{n}=4$ ) given by:

Viability $=\left(\right.$ mean $O D_{570} \mathrm{~nm}_{-}$sample $/$mean $O D_{570} \mathrm{~nm}_{-}$control $) \times 100 \%$

Equation (6)

The significant levels were examined with Student's $t$-test and ranked as $P<0.05$ or $P<0.01$.

\subsection{Cells uptake of FITC labelled GLP-NPs and GLP}


$100 \mu \mathrm{L}$ fluorescein isothiocyanate (FITC) solution $(10 \mathrm{mg} / \mathrm{mL})$ was added into $4 \mathrm{~mL}$ of GLP-NPs and GLP solution, separately. The mixtures were stirring at $4^{\circ} \mathrm{C}$ for $24 \mathrm{~h}$ in dark. The FITC labelled GLP-NPs (fGLP-NPs) and FITC labelled GLP (fGLP) were obtained by using a Sephadex G25 column. $0.75 \mathrm{~mL}$ of fGLP-NPs $(0.08 \mathrm{mg} / \mathrm{mL})$ and fGLP $(0.08 \mathrm{mg} / \mathrm{mL})$ were added to the pre-cultured cells, including Caco-2, L02, Hep-G2 and NR8383, in 12-well plates with 4 duplicates for each concentration, and incubated at $37^{\circ} \mathrm{C}, 5 \% \mathrm{CO}_{2}$ for $24 \mathrm{~h}$. After removal of the culture medium, each dish was rapidly washed three times with PBS buffer $(0.02 \mathrm{~mol} / \mathrm{L}, \mathrm{pH} 7.4)$ and incubated with $0.2 \%$ Triton $\mathrm{X}-100$ for $5 \mathrm{~min}$, and then incubated in serum-free medium for 10 min. The samples were observed by an Olympus FluoView FV1000 confocal laser scanning microscope (excitation and emission spectrum peak wavelengths of approximately $495 \mathrm{~nm}$ and $521 \mathrm{~nm})$.

\subsection{Encapsulation of Astragaloside}

Astragaloside IV (AST IV, provided by National Institutes for Food and Drug Control) was dissolved in methanol at $10 \mathrm{mg} / \mathrm{mL}$ to obtain astragaloside stock solution. The mixed aqueous solution of astragaloside IV $(0.25 \mathrm{mg} / \mathrm{mL})$ and GLP (molar ratio $\approx 10$ AST: 1 GLP) was prepared by adding $50 \mu \mathrm{L}$ stock solution in $1.995 \mathrm{~mL}$ GLP Tris- $\mathrm{HCl}$ solution $(20 \mathrm{mM}, \mathrm{pH} 7.9$, final GLP concentration of $1.0 \mathrm{mg} / \mathrm{mL}$ ) aqueous solution. The mixture and the GLP solution were incubated at $100^{\circ} \mathrm{C}$ for $60 \mathrm{~min}$ and their average particle radius were determined.

The AST concentration in the aqueous solution or dispersions was determined with RPLC and calculated according to the linear plot of a serial concentrations of pure AST $\left(\mathrm{R}^{2}=0.9991\right)$. The AST-contained GLP solution or dispersion $(1 \mathrm{~mL})$ was filtered with ultrafiltration tube (molecular weight cut-off $100 \mathrm{kDa}$ ) at $25^{\circ} \mathrm{C}$, centrifuge at $5000 \mathrm{~g}$ for $60 \mathrm{~min}$, and rinsed with $1 \mathrm{~mL}$ Tris-HCl (20 mM, pH7.9) buffer prior to the second centrifuge filtration. The filtrates were combined and subjected to the AST content analysis. The RPLC specifications were: Eurospher 100-5 C18 column $(4.6 \times 150 \mathrm{~mm})$; flow phase: Acetonitrile/water $=32 / 68$; flow rates: 
$1.0 \mathrm{~mL} / \mathrm{min}$; detector wavelength $203 \mathrm{~nm}$; column temperature: $30^{\circ} \mathrm{C}$; volume of sample injection: $20 \mu \mathrm{L}$.

The free AST loading efficacy on the GPNs was calculated with the following equation:

$$
\begin{aligned}
& E=\frac{C-C_{1}}{C} \times 100 \% \\
& \text { E- Loading Efficacy } \\
& \text { C- Total AST concentration } \\
& C_{1} \text { - Free AST concentration }
\end{aligned}
$$$$
\text { Equation (7) }
$$

\section{RESULTS AND DISCUSSION}

\subsection{Isolation and characterization of the major water soluble licorice protein}

As shown in Fig 1(A), either in the aqueous extracts prepared at room temperature or the boiling water extracts (decocting at $100^{\circ} \mathrm{C}$ for $60 \mathrm{~min}$ ) of licorice, a major protein with molecular weight of approximately $28 \mathrm{kDa}$ was identified with SDS-PAGE. The slightly blurred protein band indicated the protein may have been glycated during the heat processing of the roots, i.e. sun-drying and/or boiling. Usually, proteins are unstable in the solution at high temperature, e.g. $100^{\circ} \mathrm{C}$ in this case, denatured and form aggregates. The boiling water extracts of licorice was treated with high speed centrifuge $(12,000 \mathrm{~g}, 15 \mathrm{~min})$ to remove visible aggregates and precipitates prior to the gel electrophoresis analysis. Therefore, the protein mentioned above is either dissolved in the aqueous extracts or evenly distributed in aqueous colloidal dispersion of licorice decoction.

After precipitation with 50\% ethanol-water solution, this glycated licorice protein (GLP) was purified with an anionic exchange chromatography (Fig 1(B), Fraction A2) followed by a hydrophobic interaction chromatography (Fig 1(D), Fraction M5). The purified GLP showed a 
single band in SDS-PAGE and has an estimated molecular weight of $28.2 \mathrm{kDa}$. Its PI was at $\mathrm{pH} 4.2\left(\mathrm{R}^{2}=0.9725\right)$, as estimated by isoelectric focusing electrophoresis (as shown in Fig $1(\mathrm{C})$ ). Its N-terminal sequence was subsequently determined as NPDGLIACYCGQYCW by Edman degradation (Table 1). Searching the N-terminal sequence in NCBI protein database resulted in no significant structural similarity with any known proteins. Hence, GLP was identified as a novel protein with unknown biological function.

\subsection{Heat-induced Self-assembly of licorice proteins}

Heat could induce the structural changes of proteins, i.e. partial unfolding of the tertiary structure and conformational changes of secondary structure. Subsequently some specific regions such as hydrophobic sites or free-SH groups are exposed, causing new intermolecular interactions and the formation of soluble particles. ${ }^{15,16}$

To investigate the heat-induced self-assembly of GLP, the particles size and $\zeta$-potential of protein aggregates prepared at different $\mathrm{pH}$ were compared. As shown in Fig 2(A), the average hydrodynamic diameter $\left(\mathrm{D}_{\mathrm{h}}\right)$ of nanoparticles prepared at $\mathrm{pH}$ 1.8, 2.1, 7.9 and 8.9 was smaller than $100 \mathrm{~nm}$. Those prepared at other $\mathrm{pH}$ were larger than $600 \mathrm{~nm}$ with visible precipitates, indicating the instability of the dispersion. The $\zeta$-potential of nanoparticles formed at $\mathrm{pH} 7.9$ is greater than those at acidic conditions, referring to a higher stability. Therefore, $\mathrm{pH} 7.9$ was selected for the following tests on the influences of heating temperature and time length on the GLP nanoparticles (GLP-NPs) assembly. As shown in Fig 2(B), the GLP-NPs with high $\zeta$ potential were produced by boiling at $100^{\circ} \mathrm{C}$ for $60 \mathrm{~min}$. Accordingly, the optimum selfassembly condition for GLP-NPs is as following: heating at $100^{\circ} \mathrm{C}$ for $60 \mathrm{~min}$ in Tris- $\mathrm{HCl}$ buffer $(\mathrm{pH}=7.9,20 \mathrm{mM})$.

\subsection{Characterisation of GLP-NPs}


As shown in SEM images, the GLP-NPs are almost sphere in shape (Fig 3(D)). The $\zeta$ potential and the average diameter were determined by the DLS measurement as $-24.3 \pm 1.7 \mathrm{mV}$ and $74.1 \pm 0.7 \mathrm{~nm}$, respectively.

A size-exclusion gel chromatography (TSK G6000) coupled with MALLS monitor was used to detect the formation of GLP nanoparticles. The amount of GLP (indicated by absorbance at $280 \mathrm{~nm}$ ) assembled into NPs (indicated by light scattering intensity) was quantified by deduction of GLP remained in free form (in real solution) from the total GLP content in the dispersion, calculated from the chromatographic peak area of A280 nm (Fig 3(A)\&(B)). As shown in Fig 3(A), fraction P1 with retention time of 20.0 min contains GLP, as confirmed by SDS-PAGE. A new fraction P2 with retention time of 15.5 min appeared in the heat-treated GLP solution, while the fraction P1 decreased significantly, as shown in Fig 3(B). Fraction P2 exhibited strong light scattering intensities, suggesting the formation of GLP-NPs. Over eighty percent of GLP was assembled to spherical NPs at the optimum conditions, which was in good agreement with the heat-induced $88 \%$ loss in soluble proteins determined with Folin-Phenol assay.

The molecular weight of GLP-NPs was calculated to be $1073.23 \mathrm{kDa}$ by MALLS, while that of GLP was $47.13 \mathrm{kDa}$. Accordingly, it could be estimated that approximately twenty-three GLP molecules are assembled into one nanoparticle. The difference in the calculated molecular mass obtained by different methods of MALLS and SDS-PAGE might be caused by the possible bias in $\mathrm{dn} / \mathrm{dc}$ values. Instead of measuring the authentic value, the $\mathrm{dn} / \mathrm{dc}$ of GLP-NPs was set to be $0.185 \mathrm{~mL} / \mathrm{g}$ as a universal value for protein solutions.

As showed in Fig 3(C), the GLP-NPs responded to $\mathrm{pH}$. When adjusting the dispersion from neutral ( $\mathrm{pH} 7$ ) to acidic ( $\mathrm{pH} 3$ to 6) $\mathrm{pH}$, the mean diameter of NPs increased dramatically from less than $100 \mathrm{~nm}$ to more than $1500 \mathrm{~nm}$. This significant growth in particle size was caused by agglomeration of nanoparticles rather than the swelling/shrinking behaviour of the individual 
nanoparticle. GLP-NPs showed similar surface charges with GLP. At the $\mathrm{pH}$ around PI of GLP, weak surface charges inclined GLP-NPs to agglomerate. However, the particle size dropped back to less than $200 \mathrm{~nm}$ when the dispersion became more acidic, e.g. $\mathrm{pH} 2$. In basic $\mathrm{pH}$ ranged from 7 to 11, the diameter of GLP-NPs increased mildly, which can be explained by the more detached amino acid chains within the particles and the overall swelling of particles. Obviously, remarkable pH-responsive properties of GLP-NPs imply its great potential in the control release of drugs, phytochemicals and nutraceuticals.

The GLP protein was not the only case of plant-source proteins that self-assemble into nanoparticles in boiling aqueous solution. It was previously reported that twelve SP1 proteins from Aspen were able to self-assemble into oligomers with diameter of $11 \mathrm{~nm}$ in boiling aqueous solution. The water soluble SP1 oligomer formed large ordered arrays, and was capable of binding gold nanoparticles (GNPs). ${ }^{17,18}$ More recently, another study revealed that proteins (namely BLGs) from Radix Isatidis were capable of self-assembly into water soluble nanoparticles with average size of $120 \mathrm{~nm}$ in boiling aqueous solution. ${ }^{7}$

\subsection{Cytotoxicity of GLP-NPs and GLP}

The isolated GLP-NPs were subjected to assess the cytotoxicity on four cell lines originated from three different organs, e.g. L02, MDCK, HepG2 and Caco-2. There was only minor difference in cytotoxicity between the GLP and GLP-NPs. The maximum non-toxic concentration of GLP was $128 \mu \mathrm{g} / \mathrm{mL}$, whereas that of GLP-NPs was $112 \mu \mathrm{g} / \mathrm{mL}$. As shown in Fig 4, the GLP-NPs showed low cytotoxicity on hepatocytes (viability dropped by 34\%) at the concentrations as high as $224 \mu \mathrm{g} / \mathrm{mL}$, while the maximum non-toxic concentration for the epithelial cells (MDCK) and intestinal mucosa cells (Caco-2) is $112 \mu \mathrm{g} / \mathrm{mL}$. For comparison, the non-toxic concentration of the purified GLP for all the cell lines was $128 \mu \mathrm{g} / \mathrm{mL}$. Therefore, the self-assembly into nanostructures did not significantly change the cytotoxicity of GLP protein. 
Nonetheless, GLP-NPs promoted the growth of normal and carcinogenic hepatocytes at 14, $28,56 \mu \mathrm{g} / \mathrm{mL}$, while the GLP did so at $16,32,64 \mu \mathrm{g} / \mathrm{mL}$. The highest proliferation rates of GLP-NPs were $67.0 \pm 7.9 \%$ on normal hepatocytes L-02 and $29.2 \pm 8.5 \%$ on carcinogenic hepatocytes Hep-G2, whereas those of GLP were $36.2 \pm 4.6 \%$ and $40.0 \pm 4.2 \%$. The GLP-NPs appeared to be more favourable on promoting proliferation of the normal liver cells than the carcinogenic one, while the GLP did not show any preference.

\subsection{Cellular uptake of FITC labelled GLP-NPs and GLP}

To determine whether GLP-NPs and GLP were selectively internalized by different cells including Caco-2, L02, Hep-G2 and macrophage NR8383, GLP-NPs and GLP were labelled by FITC and then incubated with the above cells for $24 \mathrm{~h}$. As shown in Figure 7, the protein (fGLP) was internalized by none of the cells, while the nanoparticles (fGLP-NPs) were internalized by all the cells, suggesting that assembly of nanoscale structures might endow GLP with the penetrative ability across cell membrane, resulting in an increased cellular uptake. According to the strength of green fluorescence, macrophages NR8383 internalized more abundant number of fGLP-NPs than the other cells. This should be attributed to engulfment capability of the macrophages on exogenous micro-/nano-scale particles. ${ }^{19}$ There was no obvious difference on the uptake of the NPs among the other three types of cells.

\subsection{Encapsulation of Astragaloside IV}

Astragaloside IV is one of the main active components of Radix Astragali, possessing various biological activities, including anti-inflammatory, immunoregulatory, antioxidant and anti-aging. Known as a small molecular saponin, astragaloside IV is water-insoluble and poorly bioavailable in oral administration. However, the astragaloside containing herbal decoction has proven to be potent in its clinic therapeutic effects. ${ }^{20,21}$ In practice, radix Astragali is frequently used together with licorice in TCM formulae. Hence we hypothesized that licorice might help 
to increase the bioavailability of phytochemicals from radix Astragali, i.e. astragaloside IV, since the licorice has shown such capability as reported earlier ${ }^{22}$.

Astragaloside IV-loaded GLP-NPs were prepared by mixing astragaloside IV (at final concentration of $0.25 \mathrm{mg} / \mathrm{mL}$ ) and GLP (at final concentration of $1.0 \mathrm{mg} / \mathrm{mL}$ ) and incubated at $100^{\circ} \mathrm{C}$ for $60 \mathrm{~min}$. The harvested astragaloside IV-loaded GLP-NPs are spherical and negatively charged nanoparticles with average diameter of $85.8 \pm 1.7 \mathrm{~nm}$ and $\zeta$-potential of 20.5 $\pm 3.2 \mathrm{mV}$. Comparing to GLP-NPs, encapsulation of astragaloside increased the diameter of NPs by $16 \%$ and doubled the scattering light intensity of NPs at pH7.9. A similar enlargement has been observed on doxorurubicin-loaded BSA nanoparticles ${ }^{23}$ and aconitineencapsulated licorice protein NPs. ${ }^{24}$

Astragaloside IV loading efficiency of GLP-NPs was assessed by ultrafiltration (molecular weight cut-off $100 \mathrm{kDa}$ ) in couple with reversed-phase liquid chromatography. Astragaloside was identified both in the NPs $(113 \mu \mathrm{g} / \mathrm{mL})$ and in the filtrates $(107 \mu \mathrm{g} / \mathrm{mL})$. The loading efficiency was $51.8 \pm 4.6 \%$ by encapsulation with a protein/astragaloside molar ratio of $1 / 10$. The loading percentage of astragaloside IV in GLP-NPs was $14 \%$. The NPs increased the solubility of astragaloside by 5 times, as the native solubility was $22.2 \mu \mathrm{g} / \mathrm{mL}$ in neutral aqueous solution at $25^{\circ} \mathrm{C} .{ }^{25}$ In comparison, the inclusion of astragaloside to 2-hydroxypropylbeta-cyclodextrin (HPCD) increased the solubility of astragaloside to $286.8 \mu \mathrm{g} / \mathrm{mL}$ at a molar ratio of 1:1. As described earlier, approximately 23 GLP molecules compose one nanoparticle. Accordingly, the amount of astragaloside molecules encapsulated in one nanoparticle is estimated to be over 110 , noting over $80 \%$ of GLP has assembled into particles. Increasing the molar ratio between the GLP and astragaloside may further improve the solubility of AST.

Phytochemical and pharmacological studies on herbal extracts have been carried out in the past a few decades, which have led to the discovery of thousands of bioactive compounds. ${ }^{26,27}$ Proteins have been also included in this chemical prospecting among medicinal herbs, with a 
major focus on their bioactivities i.e. antivirus, antimicrobial, antitumor and enzymatic activities. However, neither their bioactivities nor their structures were barely believed to be reserved after boiling. Therefore, proteins were scarcely studied in herbal decoctions as the principle components to explain the pharmacological mechanism of herbs.

According to TCM theory, licorice plays very important role in harmonizing and modifying other herbs in a prescription, which appears to be concordant with the concept of drug delivery. Further investigating amphipathic macromolecules' heat-induced assemblies and their interactions with phytochemicals in TCM decoction may hopefully elucidate the mechanism behind. In this sense, decocting, which is the earliest and most popular method of preparation in the practice of traditional Chinese medicine, could serendipitously be a method for producing endogenous protein nanoparticles. Furthermore, screening of heat induced selfassembled proteins will provide new raw materials for protein nanocarriers.

In conclusion, GLP, a novel protein with unknown biological function and a molecular weight of $28 \mathrm{kDa}$ was purified from licorice by a two-step chromatographic separation in this study. By boiling in the aqueous solution, $80 \%$ of GLP were assembled into nanoparticles with an average diameter of $74.1 \pm 0.7 \mathrm{~nm}$. The GLP-NPs exhibited a sensitive response to $\mathrm{pH}$, a low cytotoxicity and a penetrative ability across cell membrane. Furthermore, the NPs solubilized the insoluble astragaloside IV by encapsulation. Those results suggest a great potential for GLP-NPs as a promising prototype of drug vehicle, a novel source of bioactive nanomaterials from herbal proteins, as well as a new mode of function with herbal components.

\section{FUNDING SOURCES}

This study was supported by the National Key Research and Development Plan (2016YFD0400202), National Natural Science Foundation of China (Grant No.31571803). 


\section{REFERENCES}

(1) Huang, K. C. The Pharmacology of Chinese Herbs, 2nd ed.; Routledge: New York, 1998.

(2) Guo, J.; Shang, E.; Zhao, J.; Fan, X.; Duan, J.; Qian, D.; Tao, W.; Tang, Y. Data Mining and Frequency Analysis for Licorice as a "Two-Face" Herb in Chinese Formulae Based on Chinese Formulae Database. Phytomedicine Int. J. Phyther. Phytopharm. 2014, 21 (11), $1281-1286$.

(3) Marjan Nassiri, A.; Hossein, H. Review of Pharmacological Effects of Glycyrrhiza Sp. and Its Bioactive Compounds. Phyther. Res. 2010, 22 (6), 709-724.

(4) Isbrucker, R. A.; Burdock, G. A. Risk and Safety Assessment on the Consumption of Licorice Root (Glycyrrhiza Sp.), Its Extract and Powder as a Food Ingredient, with Emphasis on the Pharmacology and Toxicology of Glycyrrhizin. Regul Toxicol Pharmacol 2006, 46 (3), 167-192.

(5) Zhuang, Y.; Yan, J.; Zhu, W.; Chen, L.; Liang, D.; Xu, X. Can the Aggregation Be a New Approach for Understanding the Mechanism of Traditional Chinese Medicine? J. Ethnopharmacol. 2008, 117 (2), 378-384.

(6) Zhou, J.; Gao, G.; Chu, Q.; Wang, H.; Rao, P.; Ke, L. Chromatographic Isolation of Nanoparticles from Ma-Xing-Shi-Gan-Tang Decoction and Their Characterization. J. EthnoPharmocology 2014, 151 (3), 1116-1123.

(7) Zhou, J.; Liu, J.; Lin, D.; Gao, G.; Wang, H.; Guo, J.; Rao, P.; Ke, L. Boiling-Induced Nanoparticles and Their Constitutive Proteins from Isatis Indigotica Fort. Root Decoction: Purification and Identification. J. Tradit. Complement. Med. 2016, 7 (2), 178-187.

(8) Weng, Q.; Cai, X.; Zhang, F.; Wang, S. Fabrication of Self-Assembled Radix Pseudostellariae Protein Nanoparticles and the Entrapment of Curcumin. Food Chem. 2019, 274 (2019), 796-802. 
(9) Tarhini, M.; Greige-Gerges, H.; Elaissari, A. Protein-Based Nanoparticles: From Preparation to Encapsulation of Active Molecules. Int. J. Pharm. 2017, 522 (1-2), 172-197. (10) Matalanis, A.; Jones, O. G.; Mcclements, D. J. Structured Biopolymer-Based Delivery Systems for Encapsulation, Protection, and Release of Lipophilic Compounds. Food Hydrocoll. 2011, 25 (8), 1865-1880.

(11) Lai, L.; Guo, H. Preparation of New 5-Fluorouracil-Loaded Zein Nanoparticles for Liver Targeting. Int. J. Pharm. 2011, 404 (1-2), 317-323.

(12) Lowry, O. H.; Rosebrough, N. J.; Farr, A. L.; Randall, R. J. Protein Measurement with the Folin Phenol Reagent. J. Biol. Chem. 1951, 193 (1), 265-275.

(13) Laemmli, U. K.; Favre, M. Maturation of the Head of Bacteriophage T4. I. DNA Packaging Events. J. Mol. Biol. 1973, 80 (4), 575-599.

(14) Loosdrecht, A.; Beelen, R.; Ossenkoppele, G.; Broekhoven, M.; Langenhuijsen, M. A Tetrazolium-Based Colorimetric MTT Assay to Quantitate Human Monocyte Mediated Cytotoxicity against Leukemic Cells from Cell Lines and Patients with Acute Myeloid Leukemia. J. Immunol. Methods 1994, 174 (1-2), 311-320.

(15) San Biagio, P. L.; Martorana, V.; Emanuele, A.; Vaiana, S. M.; Manno, M.; Bulone, D.; Palma-Vittorelli, M. B.; Palma, M. U. Interacting Processes in Protein Coagulation. Proteins Struct. Funct. Genet. 1999, 37 (1), 116-120.

(16) Rondeau, P.; Navarra, G.; Cacciabaudo, F.; Leone, M.; Bourdon, E.; Militello, V. Thermal Aggregation of Glycated Bovine Serum Albumin. Biochim. Biophys. Acta Proteins Proteomics 2010, 1804 (4), 789-798.

(17) Wang, W.; Pelah, D.; Alergand, T.; Shoseyov, O.; Altman, A. Characterization of SP1, a Stress-Responsive, Boiling-Soluble, Homo-Oligomeric Protein from Aspen. Plant Physiol. 2002, $130(2), 865-875$. 
(18) Medalsy, I.; Dgany, O.; Sowwan, M.; Cohen, H.; Yukashevska, A.; Wolf, S. G.; Wolf, A.; Koster, A.; Almog, O.; Marton, I. SP1 Protein-Based Nanostructures and Arrays. Nano Lett. 2008, 8 (2), 473-477.

(19) Hirota, K.; Ter, H. Endocytosis of Particle Formulations by Macrophages and Its Application to Clinical Treatment. In Molecular Regulation of Endocytosis; 2012.

(20) Zhang, H.; Mu, Y.; Ren, S.; Sun, M.; Liu, P. Pharmacological Effects of Astragaloside IV: A Literature Review. J. Tradit. Chinese Med. 2013, 33 (3), 413-416.

(21) Li, M.; Li, H.; Fang, F.; Deng, X.; Ma, S. Astragaloside IV Attenuates Cognitive Impairments Induced by Transient Cerebral Ischemia and Reperfusion in Mice via AntiInflammatory Mechanisms. Neurosci. Lett. 2017, 639, 114-119.

(22) Chen, L.; Xu, R.; Zou, W.; Yang, M. Investigation of Solubilization Effect from Compatibility of Glycyrrhiza Uralensis-Baphicacanthus Cusia. Chinese J. Exp. Tradit. Med. Formulae 2012, 18 (23), 17-19.

(23) Hao, H.; Ma, Q.; Huang, C.; He, F.; Yao, P. Preparation, Characterization, and in Vivo Evaluation of Doxorubicin Loaded BSA Nanoparticles with Folic Acid Modified Dextran Surface. Int. J. Pharm. 2013, 444 (1-2), 77-84.

(24) Ke, L.; Gao, G.; Shen, Y.; Zhou, J.; Rao, P. Encapsulation of Aconitine in SelfAssembled Licorice Protein Nanoparticles Reduces the Toxicity In Vivo. Nanoscale Res. Lett. 2015, 10 (1), 449.

(25) Chen, Z.; Gu, B. Enhanced Oral Bioavailability of Astragaloside IV in Rats through Complexation with 2-Hydroxypropyl-Beta-Cyclodextrin. Asian J. Pharm. Sci. 2009, 4 (1), $56-64$.

(26) Lee, K. Novel Antitumor Agents from Higher Plants. Med. Res. Rev. 1999, 19 (6), 569-596. 
(27) Gong ., X.; Sucher, N. J. Stroke Therapy in Traditional Chinese Medicine (TCM):

Prospects for Drug Discovery and Development. Phytomedicine 1999, 20, 191-196. 


\section{FIGURE CAPTIONS}

Figure 1. Extraction, isolation, purification and characterization of proteins from sun-dried licorice roots.

(A) SDS-PAGE of licorice extract. M. protein ladder; 1. Aqueous extract of sun-dried roots of Glycyrrhiza uralensis; 2. 50\% ethanol precipitation; 3. Licorice decoction. (B) High-Q anionic exchange chromatogram of proteins from aqueous extract of sun-dried licorice roots. The column was equilibrated with $20 \mathrm{mM}$ Tris$\mathrm{HCl}$ buffer ( $\mathrm{pH} 8.0$ ), and then eluted with a linear $\mathrm{NaCl}$ gradient (0-1.0 M, $200 \mathrm{~min})$ followed by rinsing with $1.0 \mathrm{M} \mathrm{NaCl}$ in the same buffer for $20 \mathrm{~min}$. The flow rate was $1.0 \mathrm{~mL} / \mathrm{min}$. The eluates were monitored with ultraviolet absorbance at $280 \mathrm{~nm}$. The subset showed the SDS-PAGE result of fraction A2, M refer to protein ladder. (C) Isoeclectric focusing electrophoresis of GLP. (D) POROS ${ }^{\circledR}$ R1 hydrophobic chromatogram of fraction A. The column was equilibrated with deionized water at flow rate $0.5 \mathrm{~mL} / \mathrm{min}$, and then eluted with a linear $\mathrm{NaCl}$ gradient $(0-1.0 \mathrm{M}, 60 \mathrm{~min})$, monitored with ultraviolet absorbance at $280 \mathrm{~nm}$. The subset showed the SDS-PAGE results of fractions. M. protein ladder, M1-M5 refer to fraction M1-M5.

Figure 2. Effects of the $\mathrm{pH}$ and temperature on forming GLP nanoparticles by heating.

(A) The average particles sizes and $\zeta$-potential of micro/nano-particles formed by boiling purified GLP for $60 \mathrm{~min}$ at different $\mathrm{pH}$. (B) The average particles sizes and $\zeta$-potential of GLP nanoparticles formed by heating at different temperatures for $60 \mathrm{~min}$ at $\mathrm{pH}$ 7.9.

Figure 3. SEC-MALLS chromatographic analysis, pH-response and SEM observation of GLP nanoparticles.

A size-exclusion gel chromatography (TSK G6000) coupled with MALLS monitor was used to detect the formation of GLP nanoparticles. The column was eluted with the citrate buffer at a flow rate of 0.5 $\mathrm{mL} / \mathrm{min}$. The elutes were continuously monitored with a UV detector (absorbance at $280 \mathrm{~nm}$ ) and a multi-angle laser light scattering detector. (A) Before boiling, TSK G6000 chromatogram for GLP solution $(1.0 \mathrm{mg} / \mathrm{mL}$, in $\mathrm{pH}=7.9,20 \mathrm{mM}$ Tris-HCl buffer). (B) After boiling, TSK G6000 chromatogram for GLP-NPs and GLP mixture. (C) pH-response of GLP-NPs. From acidic to neutral $\mathrm{pH}$, the mean 
diameter of NPs changed dramatically. (D) SEM image of GLP-NPs attached to the surface of a 0.45 mm cellulose acetate membrane. The image showed spherical NPs (pointed with arrows).

Figure 4. Cytotoxicity of GLP-NPs and GLP.

(A) Cytotoxicity of GLP on L02, MDCK, HepG2 and Caco-2 cells. (B) Cytotoxicity of GLP-NPs on L02, MDCK, HepG2 and Caco-2 cells.

Figure 5. Cellular uptake of FITC labelled GLP-NPs and GLP.

fGLP: FITC labelled GLP, fGLP-NPs: FITC labelled GLP-NPs. 


\section{TABLES}

Table 1 N-terminal sequencing results of GLP

\begin{tabular}{llllllllllllllll}
\hline Cycle & 1 & 2 & 3 & 4 & 5 & 6 & 7 & 8 & 9 & 10 & 11 & 12 & 13 & 14 & 15 \\
& & & & & & & & & & & & & & & \\
\hline Amino acid & N & P & D & G & L & L & A & C & Y & C & G & Q & Y & C & W \\
& & & & & & & & & & & & & & & \\
\hline
\end{tabular}




\section{FIGURE GRAPHICS}

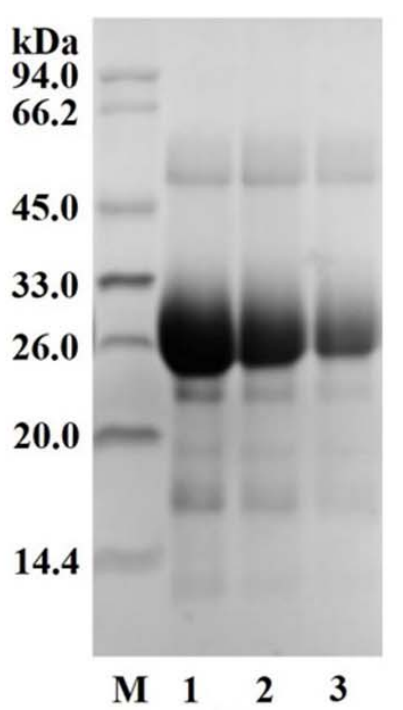

(A)

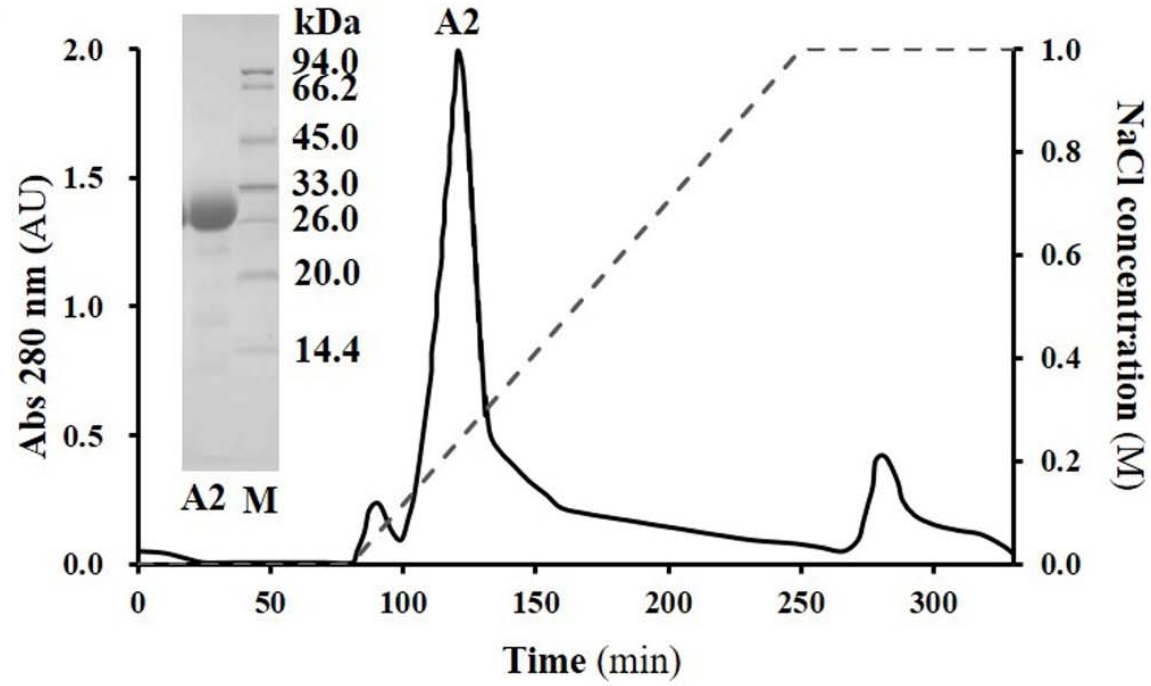

(B)

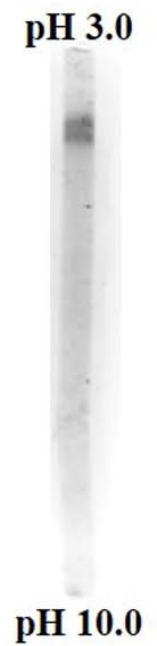

(C)

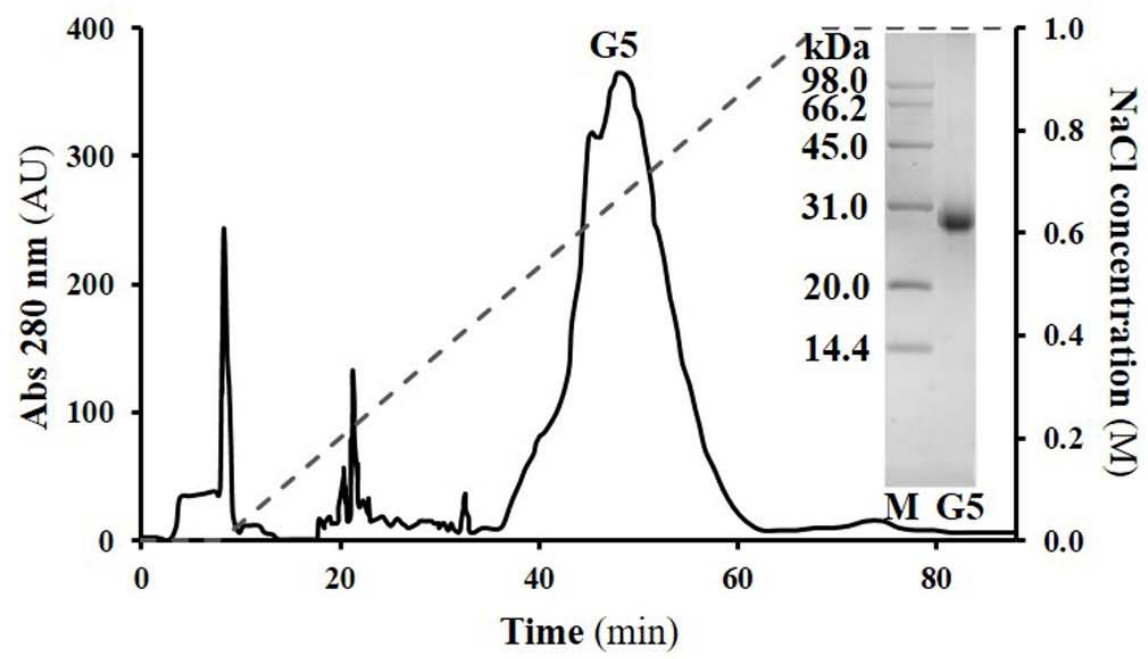

(D)

Figure 1. Extraction, isolation, purification and characterization of proteins from sun-dried licorice roots. 


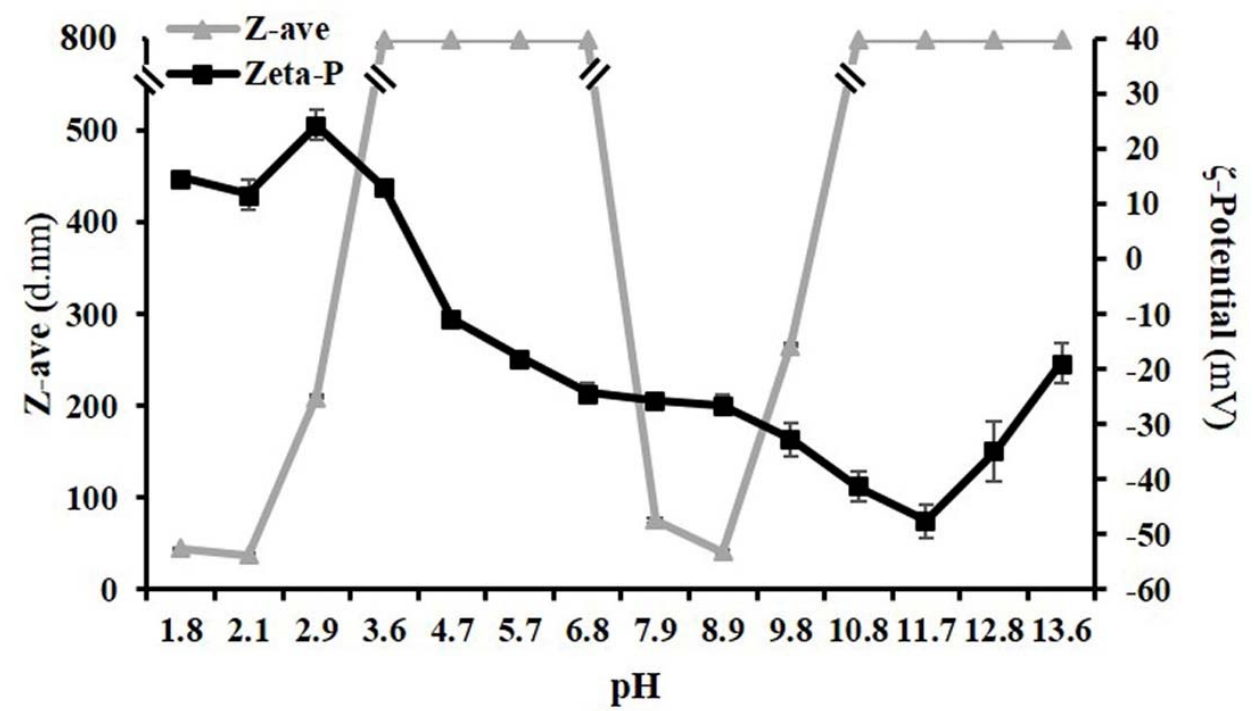

(A)

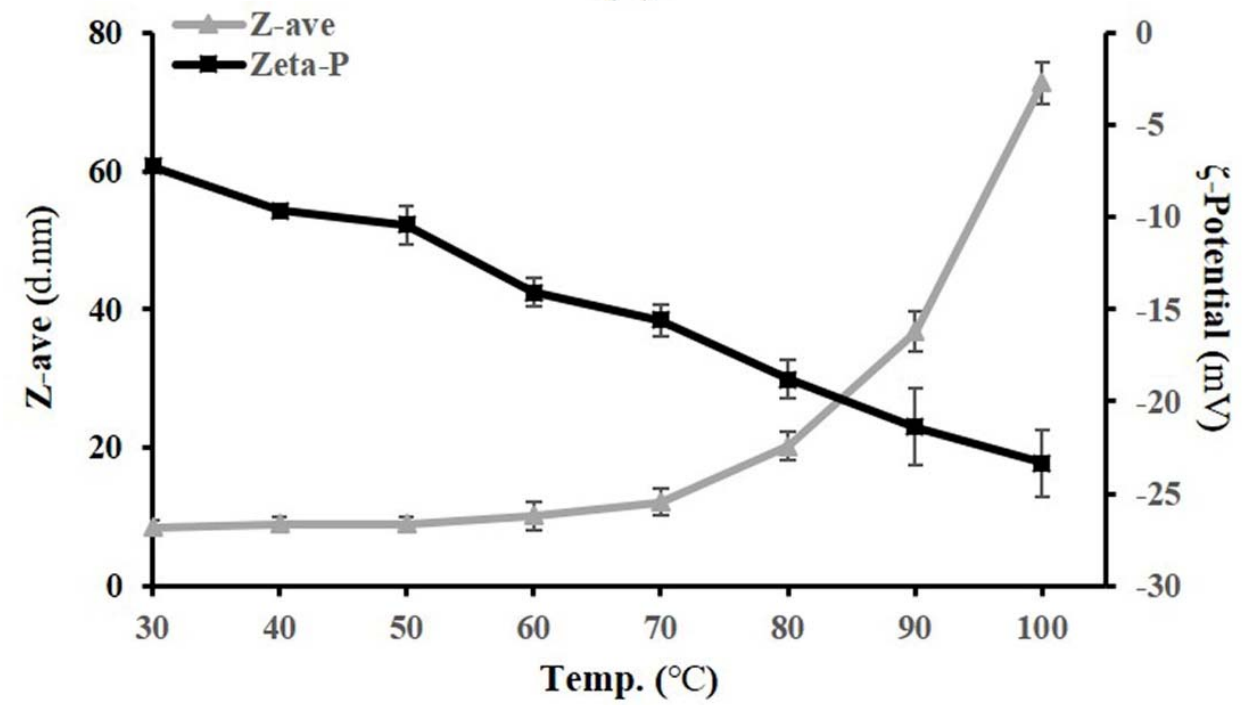

(B)

Figure 2. Effect of the $\mathrm{pH}$ and temperature on forming GLP nanoparticles by heating. 


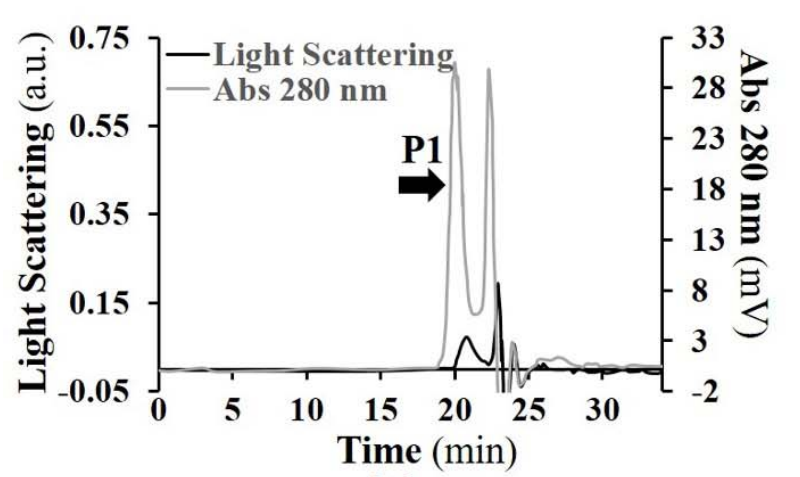

(A)

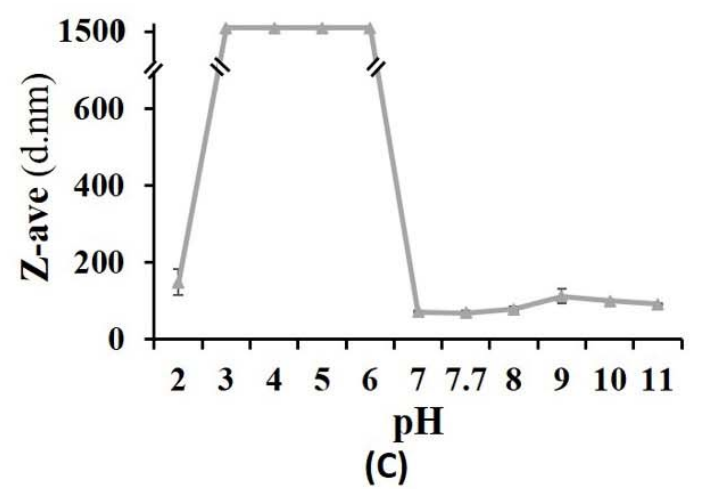

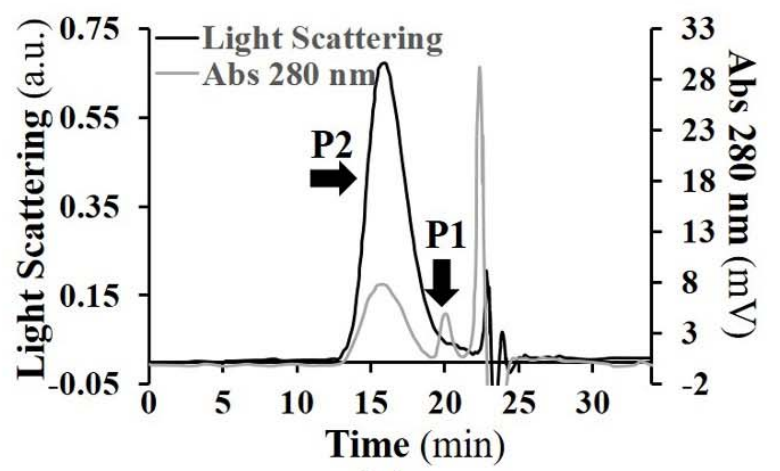

(B)

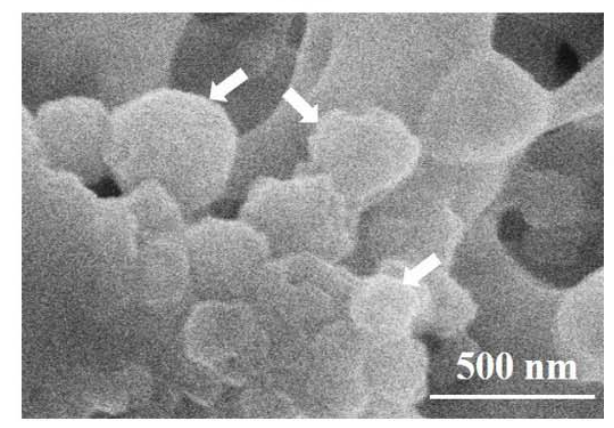

(D)

Figure 3. SEC-MALLS chromatographic analysis, pH-response and SEM observation of GLP nanoparticles. 


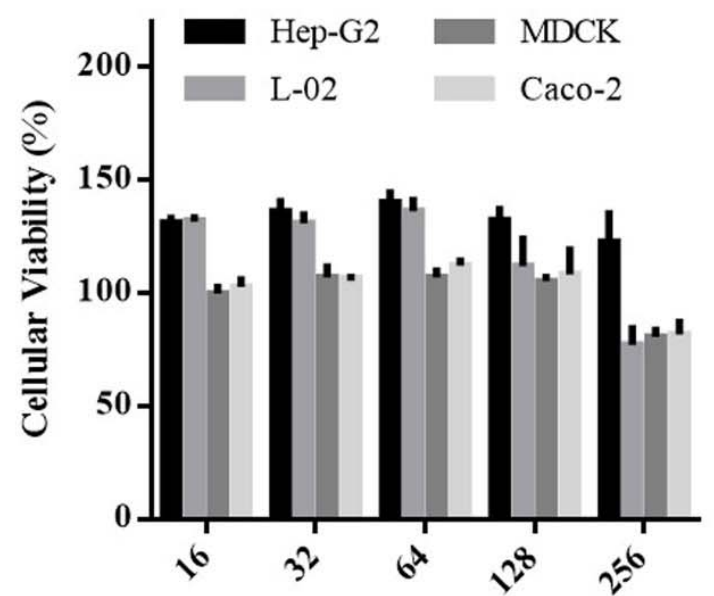

Protein Concentration of GLP $(\mu \mathrm{g} / \mathrm{mL})$

(A)

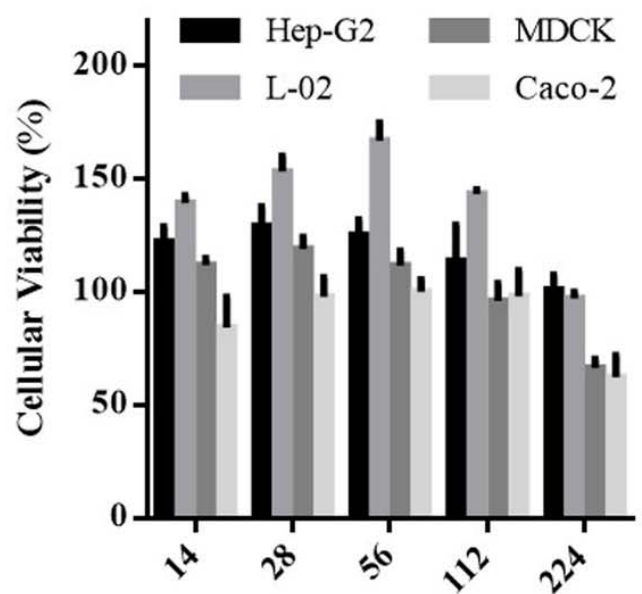

Protein Concentration of GLP-NP $(\mu \mathrm{g} / \mathrm{mL})$

(B)

Figure 4. Cytotoxicity of GLP-NPs and GLP. 


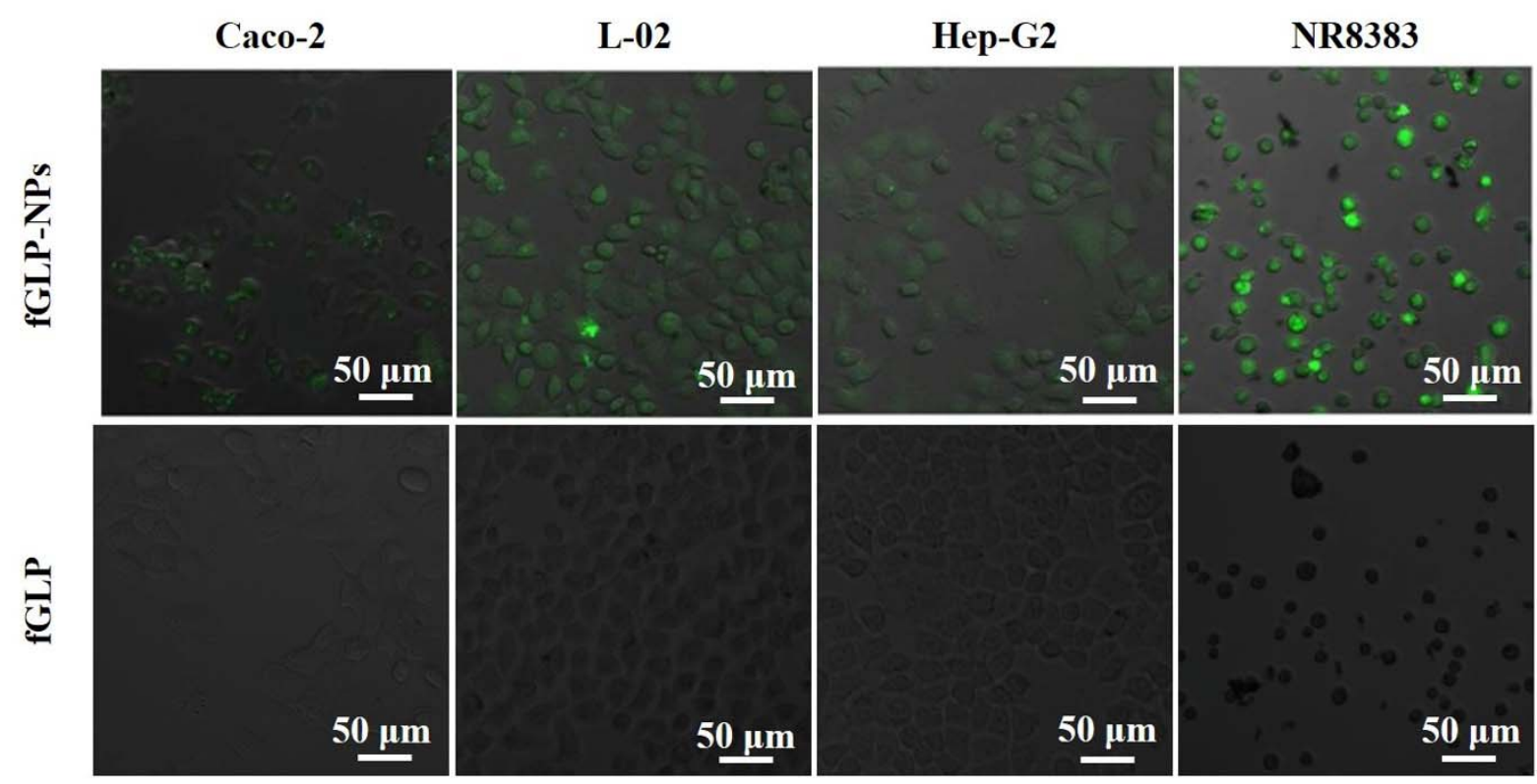

Figure 5. Cellular uptake of FITC labelled GLP-NPs and GLP 


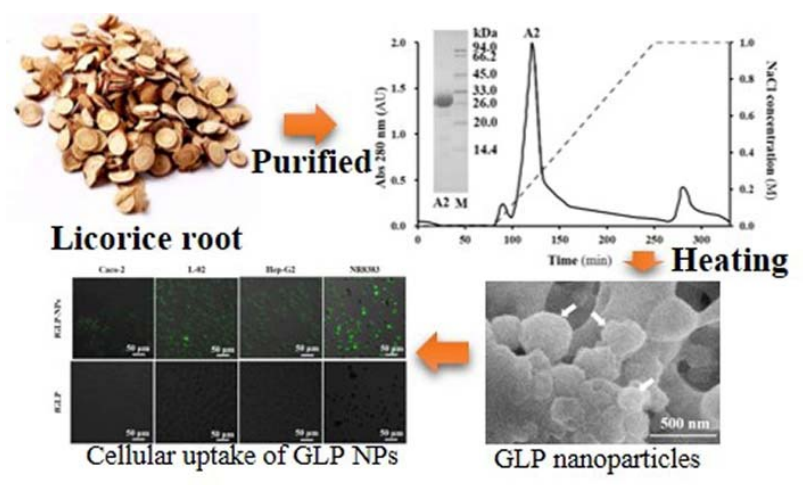

TABLE OF CONTENTS GRAPHICS 